\title{
A Brief Chronology
}

I 846 First Dutch military expedition to Bali

I 848 Second Dutch military expedition to Bali

I 849 Third Dutch military expedition to Bali; Buleleng and Jembrana defeated, brought under indirect rule

I 882 Jembrana and Buleleng brought under direct rule

I 896 Karangasem brought under indirect rule

I90 I Gianyar brought under indirect rule

I906 Badung defeated, brought under direct rule

I906 Tabanan defeated, brought under direct rule

1908 Klungkung defeated, brought under direct rule

r 909 Bangli brought under indirect rule

1917 Earthquake in Bali destroys temples and villages

I9I 7 Bangli and Gianyar brought under direct rule

I92 I Karangasem brought under direct rule

1922 New land-tax ordinance in Bali

1929 Former rajas granted royal titles and privileges

1938 Restoration of zelfbestuur in Bali

I 8 Feb. I 942 Japanese forces occupy Bali

9 March 1942

24 May 1945

Netherlands Indies authorities surrender to Japanese

I4 Aug. I945

Sukarno visits Bali

Japanese capitulate

I7 Aug. I945 Indonesian independence proclaimed

8 Oct. 1945

November 1945 Japanese transfer civil administration in Bali to local Indonesian National Committee (KNI-Bali)

I 3 Dec. 1945

Pemuda groups PRI and Pesindo established in Bali

29 Jan. 1946

Republicans attack Japanese installations in Denpasar

2 March 1946

KNI-Bali transfers authority to rajas and Paruman Agung

Netherlands Indies (KNIL) troops land at Sanur Beach

State of War and Siege (SOB) declared in Bali

I I March 1946

Governor I Gusti Ketut Puja and other KNI-Bali members arrested by KNIL forces in Singaraja

July 1946 Malino Conference to discuss formation of federal states 
November 1946

20 Nov. 1946

6 Dec. 1946

December 1946

25 March 1947

April 1947

April 1947

June 1947

2I July 1947

July 1947

I 5 Jan. I 948

I 7 Jan. I 948

24 May 1948

September 1948

I 9 Dec. 1948

3 Mar. 1949

7 May 1949

Mid-I 949

August 1949

I7 Aug. I 949

5 Sept. 1949

December I 949

January 1950

August 1950

September 1950

I 5 May 195 I

December I95 I

29 July 1955

I 5 Dec. 1955

I4 May 1957

I4 Aug. 1958

July 1959

1960

1960

I7 March 1963

I May 1963

I6 May 1963

I Oct. 1965

7 Dec. 1965
Linggajati Accord between Netherlands and Republic of Indonesia drafted

Battle at Marga; 96 Republican troops killed in one day

Partai Rakyat Indonesia (Parrindo) formed in Bali

Denpasar Conference to establish federal states

State of East Indonesia (NIT) established

Linggajati Accord ratified by Netherlands

Balinese resistance organization (MBU-DPRI) frames "Minimum Program" in response to Linggajati Accord

Elections for Paruman Agung; results annulled in Badung and

Buleleng

Parrindo banned

First Dutch military action begins on Java

MBU-DPRI issues "New Struggle Program" in response to Dutch military action

Renville Agreement signed

Republic of Indonesia recognizes NIT

MBU-DPRI issues "special instruction" leading to "surrender" of at least I,, 00 resistance fighters

New elections for Paruman Agung

Second Dutch military action begins on Java

Civil authority transferred to chair of Council of Rajas

Roem-van Royen Agreement signed

SOB lifted in Bali

Festival of Jayaprana at Kalianget, Buleleng

Gerakan Nasionalis Indonesia (GNI) formed in Bali

Gerakan Pemuda Indonesia (Gerpindo) formed in Bali

Transfer of sovereignty to Indonesia

SOB declared in Bali

Unitary Republic formed

Suteja selected as kepala daerah of Bali

Paruman Agung dissolved, replaced by DPRD-Bali

SOB lifted in Bali

Thirteen Balinese pemuda to Jakarta to meet Sukarno

National parliamentary elections

National elections for Constituent Assembly

Declaration of martial law (national)

Bali gains provincial status

Suteja selected as governor of Bali

I 945 constitution restored

Sukarno assumes role of Supreme War Authority

National land-reform laws enacted

First eruption of Gunung Agung

Martial law lifted

Second eruption of Gunung Agung

Untung coup (G-3o-S) and Suharto countercoup

RPKAD and Brawijaya troops land on Bali from Java, massacre begins 
The Dark Side of Paradise 
